\title{
A COGNITIVE APPROACH TO THE COMPILATION OF TEST MATERIALS FOR THE EVALUATION OF TRANSLATOR'S SKILLS
}

\begin{abstract}
This paper discusses the importance of a cognitive approach to the evaluation of translator's skills. The authors set forth their recommendations for the compilation of test materials for the evaluation of translators' cognitive ability.
\end{abstract}

Keywords: translation quality; general cognitive ability; translators' cognitive ability; evaluation of translators; cognitive ability

The globalization of economic, social and cultural life that has taken place in recent decades has led to a rapid increase in the number of international enterprises, projects and programs. This inevitably results in the increase of data flow, including the exchange of information between speakers of different languages. Therefore, the establishment of efficient communication between languages has become an ever-more pressing need (Webster, 2006, p. 83).

This need is met by translation. Demand for translation has kept growing steadily, even at a time of economic crisis (European Commission, Directorate-General for Translation, 2009, p. 20). However, as the EC Report stated, "The constant increase in the number of translation companies results in a situation where supply continuously exceeds demand. The number of well-qualified linguists, however, is too small to cover the growing need" (European Commission, DirectorateGeneral for Translation, 2009, p. 24). This implies that translation quality assurance is a problem which is yet to be fully solved.

The Art of Translation is a National Asset, an open letter sent by the Russian Translators' Union to the President and the Government of the Russian Federation on May 8, 2015, also states that "At this time the quality of translation is jeopardized and one of the reasons for this is the massive inflow of poorly skilled people into our profession. To some extent it can be mitigated through the professional certification of the translation workforce" (http://www. translators-union.ru/). Clearly, well-qualified linguists are a mandatory condition for the assurance of high-quality translation and, consequently, skills evaluation should be undertaken when selecting translators for each particular project.

This skills evaluation involves using test materials of various types. A team of researchers from several Australian universities, led by Professor Sandra Hale, studied translator certification 
systems worldwide (Hale, 2012). Their review describes certification systems adopted in Australia, as well as in the Americas, Europe, Asia and South Africa. In the study, certification systems were categorized based on the identification of the educational requirements of potential translators (ie: academic qualifications) and specific certification programs (medical translation, legal translation, etc.) (Hale, 2012, pp. 20-29]. In addition to this, the study provides general concepts for the translation evaluation adopted in each of the countries reviewed. These concepts mainly consist of counting errors of different types, with a points total given for translation quality. (Hale, 2012, pp. 58-64).

The most detailed description provided by the review is that of the test conducted in Australia by the National Accreditation Authority for Translators and Interpreters. In particular, it indicates the size and the number of tests to be given for certification translation, as well as the reference materials the translators are allowed to use when doing the translation. "Most commonly they [translators] are judged against the competencies, skills and body of knowledge a practitioner is expected to have" (Hale, 2012, p. 47).

The American Translators Association provides the following information on the certification test it offers: "a translator must pass a challenging three-hour exam. The exam assesses the language skills of a professional translator: comprehension of the source-language text, translation techniques, and writing in the target language" (https://www.atanet.org).

The Russian Translators' Union (RTU) is not inclined to disclose the principles it applies for the compilation of test materials and the establishment of translation evaluation criteria. It merely says that "The personal qualification test in a single language pair takes seven hours; translators can use reference literature and computer resources. A candidate receives three texts, each about 500 words long, which is an equivalent of two standard pages. One text is mandatory and is of general character, the second is on subjects in which the candidate claims to be skilled, and the third deals with a relevant specialization determined by the certification board. The quality of all three translations should meet the threshold score set by the RTU's Scientific and Methodology Board for translators of scientific and technology materials and documentation to be certified for the first and the highest categories. Prior to the beginning of the test each candidate should sign a notice that indicates that he/she is entitled to receive only the final result of the test without any comments from the evaluators and that he/she has been made aware that he/she will not have access to the checked and evaluated translation, which will become the property of the certification board. ... The evaluators scored detected errors using a grading system where each error adds $1 / 8,1 / 4,1 / 2$ or a whole point to the total error score. These penalty points can be reduced by subtraction of up to three points in each text as a bonus for "good translation solutions" (http://www.translators-union.ru).

The Institute of Translation and Interpreting in St. Petersburg provides a more informative description of the tests which it conducts. "Various types of tests can be taken in the Laboratory: the standard test employed by most translation agencies, a comprehensive test, a computer skills test, an evaluation of the knowledge of translation resources on the Internet; a test that evaluates automated translation skills; a lexicographic skills evaluation test (terminology search, creation of terminology bases), and a test for translation project management skills. The comprehensive test evaluates the speed of translation, computer skills and the linguistic quality of the translation. This text is the most modern and efficient way of evaluating a translator's skills" (http://translation.spbu.ru/translation-test.htm/).

Summarizing an overview of publications on the the quality of translation tests, we can observe that translation quality assessment is discussed only in the framework of general-purpose testing required to obtain a certificate. This does not cover the certification or evaluation of the ability of the translator to participate in a particular project. Besides, these works do not include descriptions of principles or methodologies that could be used to compile test materials needed for the evaluation of translator's skills. Finally, they discuss only linguistic skills (hands-on competence in the source and target languages) and communicative skills (competence in different types of written and oral communication activities), while the cognitive ability of the translator is not 
evaluated and, in fact, is not even mentioned.

The experience gained in more than 20 years of work at Language Interface (New York, USA), a translation company where the authors are employed, proves that a cognitive approach to the evaluation of translators is even more important than one based on linguistic competence or communicative skills. Besides, the evaluation of translators' skills with regard to working on a particular project is a completely different type of assessment from general-purpose testing. This task calls for extensive work aimed at the compilation of test materials that enable the evaluators to assess the translators' skills in an adequate and efficient manner.

Since translators deal with natural texts only, no artificially produced texts should be used in the compilation of tests. Due to many reasons, translators are reluctant to translate large test texts and, besides, the evaluation of a large translation is a labor-intensive task. For this reason, the size of the text should not exceed one page. The best approach is to compile tests based on actual documentation that has undergone translation. Ideally, the test should be comprised of two or three fragments on different subjects. Due to the required brevity of the test, the texts will inevitably be taken out of context, so in order to enable the translator to produce a high quality translation (which is impossible without the context), some background information should be provided along with the text.

Developers of test materials should compile texts that will enable the evaluators to acquire the maximum information from the translation of a few paragraphs. At first glance it seems to be very difficult to make any certain conclusions on the linguistic and communicative competences of the candidate, and absolutely impossible to identify his or her cognitive abilities. Despite this difficulty, analysis of Language Interface's experience in numerous international projects, which inevitably involve a selection of translators, enabled us to formulate some recommendations for the development of test materials for the evaluation of translators applying for a position on an international project. As has already been mentioned, this selection should be focused on the identification of the cognitive abilities of the candidate.

In international projects, the cognitive ability of the translator becomes a critical component of his or her skills because the translator often faces non-standard problems that cannot be resolved by using good knowledge of the source and target languages alone. In addition to a broad vocabulary and grammar knowledge, as well as experience in translation in certain fields (such as oil and gas, space industry, medicine etc.), the translator should have the ability to perform such universal actions as comparison, analysis, synthesis, abstraction, generalization, classification, specification and the detection of patterns and rules. The translator should be capable of maintaining active and intense cognitive actions: logical reasoning, research and analytical work and decision-making.

International cooperation is always at the cutting edge of scientific, cultural or social life and this is why texts that need to be translated in order to cover the vital needs of international projects are often very complicated and, as a rule, have an abundance of new terms and acronyms.

To some extent, the cognitive abilities of a translator can be judged by examining virtually any translation he or she has produced. The quantity and nature of lexical, grammatical and stylistic errors found in the translation serve as indirect indicators of cognitive ability, while incoherent translation is an obvious evidence of poor skills. Less obvious, but not less important, is the detection of shortcomings in the cognitive ability of a translator who delivers a translation that is consistent $t$ (i.e. a text that, at the first glance, has coherent meaning and correct grammatical links between words and expressions), but carries no meaning. As an example, in a test translation of an excerpt from the Building Code Requirements for Structural Concrete developed by the American Concrete Institute, one Moscow translator produced complete nonsense. The source text reads: This Code does not govern design and installation of portions of concrete piles, drilled piers, and caissons embedded in ground except for structures assigned to Seismic Design Categories D, E, and $F$. This Code does not govern design and construction of slabs-on-ground, unless the slab transmits vertical loads or lateral forces from other portions of the structure to the soil. Chord reinforcement provided near wall edges in concentrated amounts for resisting bending moment is not 
to be included in determining $\rho$ t and $\rho$. Within practical limits, shear reinforcement distribution should be uniform and at a small spacing.

The translation stated: Код строительства из бетона. Код не определяет дизайн и установку пориий бетонных пакетов, буровых свай и одноопорных морских эксплуатационных платформ в структурах, приписанных Сейсмическим Категориям Дизайна D, E и F. Этот код не влияет на дизайн и конструкцию нависающего слоя породы на земле, если только данная конструкция не пересекает вертикальные грузы или латеральные силы из других частей земляной структуры. Поясная арматура, расположенная возле стенных торцов в концентрированном количестве для сопротивления изгибному моменту не должна быть включена в определение $\rho t$ u $\rho$. B практических пределах поперечная арматура должна быть однообразной и на маленьких расстояниях.

A fragment from the United Nations' Millennium Development Goals Report for the year of 2010 , translated by a candidate for a position on the translation team of an international project, reads: Саммит будет проводитвся в условиях неоднозначного прогресса и новых препятствий, затрудняющих усилия мирового сообщества по сокращению наполовину нижснего уровня бедности.

We suggest that it is possible to establish certain formal components of a test text that can serve as metrics of a translator's cognitive ability. These components often present challenges even to translators who demonstrate a good knowledge of languages (both source and target) and usually deliver coherent and meaningful translations. When encountering such difficulties, the translators introduce inaccuracies, intentional omissions of fragments of the source text, or meaningless translations. We believe that including such potentially problematic components in the translation text is practical and necessary.

Translation difficulties emerge when there are no direct semantic equivalents between the source and target texts. For example, for an American plumber Schedule 40 is one of the basic concepts that defines piping size. For a Russian plumber, the translation Сортамент 40, even though it is a correct one, means nothing since it points to a non-existing place in the recipient's mind. This is why, when translating a Construction Code established by the American Society of Mechanical Engineers (ASME) that under the contract should be observed by Russian specialists, a verbatim (i.e. formally correct) translation makes no sense. In cases of this type, it is necessary to know which Russian regulatory concept is equivalent to this particular American concept, and to use that equivalent in the translation.

Rare, special terms encountered in the source text also often cause difficulties. Введение новой схемы расчетов межоператорских тарифов привело к тому, что приземление вызова сотового абонента на сеть фиксированного оператора стало обходиться сотовым операторам дешевле, чем приземление вызова фиксированного абонента на сеть сотового оператора. In order to adequately translate this fragment, the translator has to discover what приземление вызов $a$ is and find the equivalent of this term in the target language. A translator capable of doing research will not translate this special term based on the commonly used meanings of each word this expression is made of (call landing), as many candidates did, but will select the term from the telecommunications sublanguage: mobile to landline call divert.

The selection of the appropriate meaning of a polysemantic word or expression in a given text often poses a problem as well. In one project, an original shipping waybill in English containing a list of shipped items stated $6 \mathrm{~mm}$ drill bits. This was translated as комплект буровых долот диаметром 6 мм. In fact, буровое долото is a correct equivalent of the lexical unit drill bit. However, it is not the only one. Another meaning of is сверло. The diameter of the bit indicated in the waybill $(6 \mathrm{~mm})$ clearly points to the latter meaning of the term.

Another example is a test translation of an excerpt from a description of an oil well design: Outside the borehole is rock formation. Some translators, most of whom were not familiar with geological subjects, made an effort to find correct the semantic equivalent of the term rock: CHaружи ствола скважины залегает порода. Others used the word камень, which is irrelevant in this context: Скважина, снаружи окруженная камнем. 
When translating a Russian text on the industrial application of tungsten into English, the phrase Вольфрамовая проволока широко используется в электрических лампах и изделиях электронной техники в качестве тела накала, электродов, сеток и др. was translated as "Tungsten wire is widely used in electric lamps and electronic products as filaments, electrodes, reticles, etc.". Here, for translation of the word cemкa the translator chose to use the English word reticle which means "a net of fine lines or fibers" (from the Latin reticulum). Even though the translator's knowledge system may not include knowledge of the industrial applications of tungsten, a specialist with strong cognitive ability would wonder why a net would be made of such a rare metal as tungsten. Research in technical literature on electronic devices helps to understand that вольфрамовые сетки (tungsten grids) are not meshes or nets consisting of crossing lines, but the electrodes of vacuum tubes (diodes, triodes etc.), usually designed as spirals, and placed between the cathode and anode of the tube. These components are known in English as grids. This hypothesis was confirmed by the fact that the source document was published in 1977 when vacuum tubes were commonly used in electronics and had not been replaced by semiconductors.

The translation of acronyms is another area of difficulty. Source: Romania has a good potential to export cheap electricity to Hungary due to reasonable NTCs and generation potential. Translation: Румыния обладает хорошими потенциальными возможностями для экспорта дешевой электроэнергии в Венгрию благодаря приемлемым отрицательным температурным коэффициентам и перспективам производства энергии. The acronym NTC may stand for different terms depending on the field of knowledge in which it is used. One translator put it as отрицательный температурный коэффициент еven though such a translation destroys the meaning of the statement. In the given context, $N T C$ stood for пропускная способность линий электропередач (throughput capacity of power lines). The homonymy of acronyms can deceive the translator, even when these acronyms are commonly used. The general manager will visit the company offices in New Orleans, LA. One of the candidates translated this phrase as " $\Gamma e$ неральный менеджер посетит офисы компании в Новом Орлеане и Лос-Анджелесе", which is wrong. Even though $L A$ can denote Los Angeles, in this case this was a standard acronym of the state of Louisiana, where New Orleans is located. These acronyms denoting the state is traditionally shown after a city followed by comma, such as Seattle, WA or Chicago, IL. The correct translation of that phrase should have been "Генеральный менеджер посетит офисы компании в Новом Орлеане (штат Луизиана)".

A special case of translation difficulties is the recognition of acronyms that have only recently emerged, local acronyms that are used within a particular enterprise, or those acronyms that are arranged in lower case letters. For instance, when translating documentation for a U.S. telecommunication company, the translator could not find the meaning of the word latlon. Advice received from a company specialist clarified that this word is a non-standard use of the expression latitude and longitude adopted in the company.

A plethora of difficulties is encountered when translating foreign proper names. Firstly, errors are often made when dealing with proper names that have conventional translations. For example, in test texts taken from United Nations reports, more than a half of the candidates incorrectly translated the name of the Secretary General Ban Ki-moon. Those candidates transcribed the name and came up with Бан Ки-мун while the conventional translation of this name is Пан Ги Мун.

Secondly, translators often make errors when a foreign name is given as initials. In order to choose the correct form for many last names of foreign origin, one needs to know what gender of the person of that name since it determines whether the last name should be inflected or not. Not all translators make an effort to find out these details, which results in translations like обзор подготовлен М. Скоттом, while the author of the overview is Marilyn Scott (Мэрилин Ckomm), a female whose last name should not be inflected in Russian.

Negligence in the interpretation of initials leads to errors in translation of the initials themselves. The cause of these errors is the fact that some Latin letters may denote different sounds, depending on the language and the letter's position in the word. E.g. the initial C. may stand for 
the name Colin (Колин), Cесіl (Сесиль) or Charles (Чарльз); the initial G. can denote Garrett (Гарретm) or George (Джордж); S. - Sabrina (Сабрина), Sean (Шон) or Sigfried - Зигбpuд; J. - Jacklyn (Жаклин), Jeffrey (Джеффри), Jürgen (Юрген) or José (Хосе). Possibly, A. shall be translated as O. (e.g. in the name, Auguste - Огюст), E. - as Ю. (Eugene - Юджин and H. - as O. (Haudrey - Oдpu) or Э. (Helene - Эллен).

Moreover, not only the literal denotation of the name should be determined to produce a correct translation of the initial, but also its phonetic equivalent, because there are many names that are pronounced differently in different languages. The name Sara recovered from the initial $S$. can sound like Capa and 3apa, depending on the origin of its owner; the initial $H$. that stands for the name Henry in Russian can be Генри or Анри, therefore in translation it should be shown with different initials.

The translation of a text that contains the typical difficulties shown above enables the evaluator to identify the individual cognitive abilities of the translator: skills allowing him or her to analyze, compare, classify, specify, find patterns, and synthesize new knowledge. However, having some of these skills, or even a set of them, may be insufficient when it comes to the ability to solve complex, non-trivial problems a translator may encounter in the course of an international project.

Along with individual abilities, translators should have strong general cognitive ability (in terms of C. Spearman, 1904). Researchers (physiologists, psychologists, genetic scientists) regard this ability as an aggregate intellectual factor. It should be noted that studies of general cognitive ability are beyond the scope of translation theory or project management specialists.

The translation process is a continuous search for a balance between the need to make immediate decisions on the translation of one or another term or phrase and the necessity to question these decisions. This is why one of the critical pieces of evidence of the general cognitive ability of a translator is the ability to recognise the boundaries of his or her own knowledge. This lead him or her to question apparently evident solutions.

An example taken from the Language Interface experience demonstrates a case in point. In one project the acronyms LDPE, HDPE, LPPE, HPPE were widely used (low density polyethylene, high density polyethylene, low pressure polyethylene, high pressure polyethylene). In the Russian technical literature all four terms were also used - полиэтилен низкой/высокой плотности (ПНП, ПВП) and полиэтилен низкого/высокого давления (ПНД, ПВД). A member of the translation team who first came across this terminology reasoned that it is self-evident that high density polyethylene is manufactured under high pressure and vice versa, so he used the terms полиэтилен высокой плотности and полиэтилен высокого давления аs synonyms. The other members of the team found this completely reasonable and did not question his interpretation. This continued until one of the translators decided to check the term in a reference book. Against all expectations, it turned out that high density polyethylene is manufactured under low pressure, while low density polyethylene is made under high pressure. The translator's critical attitude towards his own knowledge and adopted practice helped to avoid a serious mistake and to deliver a correct translation to the client.

Another example: a graduation diploma issued by one U.S. college, which was originally written in Latin and submitted for translation into English, contained these words: in civitate novorum eboracensium. The composition of the word eboracensium indicates that it denotes inhabitants of Eborac, a town in the Roman province of Britain, i.e. it is a verbatim translation of the phrase in the state (or community) of new Eboracians. It is obvious that in the context of an American college diploma this phrase does not make sense. The key to this puzzle was the result of translation research that found that nowadays the city of York is situated on the site of the former Roman town of Eborac. Therefore, the authors of the text encrypted New York as new Eborac, and the use of the name of the city's inhabitants resulted from the excessive (and inappropriate) stylization. Thanks to the extraordinary cognitive ability of the translator the meaningless phrase in civitate novorum eboracensium became a meaningful one: in the state of New York, indicating the location of the college.

While we assert that a cognitive approach is the primary conceptual principle that should 
be applied in the compilation of text materials and believe that translators' general cognitive ability is very important, it must be admitted that no universal means of its evaluation when selecting translators for international projects have yet been found. Nonetheless, the general cognitive ability of a translator can be indirectly evaluated through the analysis of the ways he or she chooses to overcome typical difficulties: terms that do not have direct equivalents for their meanings, special terms, polysemantic words, acronyms, proper names and initials of foreign origin. By including these potentially problematic components in test materials, one can adequately evaluate translators' cognitive abilities, which are critical for the technical translations required for international projects.

Apparently, it is not possible to compile a perfect test that would impeccably detect translators' cognitive abilities. However, the closer a real text comes to the ideal model, components of which have been discussed in this paper, the more precise the test results will be, and the greater the likelihood of selecting the best candidates for an international project translation team. This will improve the quality of translations, which will directly influence the success of the overall international project.

\section{References}

European Commission, Directorate-General for Translation. (2009). Studies on translation and multilingualism. Kingston-upon-Thames: The Language Technology Centre Ltd.

Hale, S. (2012). Improvements to NAATI testing. The University of New South Wales. Retrieved from https://www. naati. com.au/PDF/INT/INTFinalReport.pdf.

Spearman, C. (1904). "General intelligence," objectively determined and measured. American Journal of Psychology, 15(2), 201-293. http://dx.doi.org/10.2307/1412107.

Webster, F. (2006). Theories of the information society. New York: Routledge.

\section{Acknowledgment}

This work was supported by a Language Interface Inc.

The authors declare that they have no competing interests.

The authors' contribution was as follows: concept of the study: first author; concept development: second author; data collection and analyses: both authors; the writing: both authors.

This is an Open Access article distributed under the terms of the Creative Commons Attribution 3.0 PL License (http://creativecommons.org/licenses/by/3.0/pl/), which permits redistribution, commercial and noncommercial, provided that the article is properly cited.

\section{(C) The Authors 2016}

Publisher: Institute of Slavic Studies, Polish Academy of Sciences, University of Silesia \& The Slavic Foundation 